\title{
Influenza y los virus aviar: la amenaza latente de un nuevo virus pandémico
}

\author{
Influenza and avian viruses: the latent threat of a new \\ pandemic virus
}

José de Jesús Coria-Lorenzo, ${ }^{1}$ Alfonso E Sierra-Calle, ${ }^{2}$ Gabriela Guerrero-Mendoza, ${ }^{3}$ Jorge Field-Cortázares ${ }^{4}$

\begin{abstract}
Resumen
La enfermedad por influenza aviar es una zoonosis. Son las aves migratorias las que normalmente acarrean los virus en el aparato respiratorio o intestinal. Las aves no contraen la infección, solo son reservorios del virus. Los virus aviar son propios de determinadas especies pero, en ocasiones, logran infectar al hombre. La trasmisión al humano se produce por contacto estrecho con aves no migratorias (de corral o de supermercados) infectadas o entornos muy contaminados. Los virus aviar han infectado al ser humano desde el decenio de 1990. El primero en identificarse fue el virus AH5N1 en 1997 y, posteriormente, en 1999 el AH9N2, considerado con mayor potencial pandémico. Si bien los mayores casos de infección y enfermedad en humanos han sido por $\mathrm{AH} 5$, a la fecha existen diferentes tipos de influenza aviar que han causado muertes en humanos. Destacan, además de los virus H5 y sus diferentes subtipos: AH7N7, AH7N9 y AH9N2. La enfermedad por influenza aviar no debe confundirse con la gripe humana estacional, que es común del hombre (casi siempre causada por los virus $\mathrm{H} 1$ y H3). En virtud del potencial pandémico de los virus aviar, el objetivo de esta revisión es conocer sus factores de riesgo, trasmisibilidad y epidemiología ante la inminencia de una nueva pandemia. Es necesario insistir en la vigilancia constante en poblaciones animales y humanas, investigar exhaustivamente los riesgos de infección para una planificación oportuna en caso de pandemia, como lo viene efectuando la Organización Mundial de la Salud.
\end{abstract}

PALABRAS CLAVE: Influenza aviar; zoonosis; influenza en aves; influenza humana; virus influenza A; factores de riesgo.

Abstract

The disease caused by avian influenza is a zoonosis. Migratory birds usually carry viruses in the respiratory or intestinal tract, they do not contract the infection, but are reservoirs of the virus. Avian viruses are usually specific to certain species, but on several occasions, they can infect man. Transmission to humans has occurred in close contact with infected non-migratory (poultry or poultry markets) birds or highly contaminated environments.

Apparently, there is evidence of avian viruses that have infected the human since the 90's being the first to identify the AH5N1 in 1997 and then in 1999 the AH9N2, which is considered the highest potential pandemic alert. While it is true that the majority of infection and disease in humans have been secondary to the $\mathrm{AH} 5$ virus, there are different types of avian influenza that have caused mortality in humans, including among them the $\mathrm{H} 5$ viruses and their different subtypes, and others such as: AH7N7, AH7N9, $\mathrm{H} 10 \mathrm{~N} 8$ and the AH9N2. Avian flu disease should not be confused with seasonal human flu, which is a common human disease (usually caused by the $\mathrm{H} 1$ and $\mathrm{H} 3$ viruses).

Given the pandemic potential of avian viruses, the objective of this review is to know their risk factors, transmissibility and epidemiology before the imminence of a new pandemic. So we must insist on constant vigilance in both animal and human populations, thoroughly investigating the risks of infection for timely planning in the event of a pandemic as the World Health Organization has been doing.

KEY WORDS: Avian influenza; Zoonoses; Influenza in birds; Influenza Human; Influenza A virus; Risk factors.
${ }^{1}$ Infectólogo pediatra, Hospital Infantil de México Federico Gómez, Ciudad de México.

${ }^{2}$ Pediatrician of Lowell General Hospital \& Children's Hospital of Dracut, Massachusetts, EUA.

${ }^{3}$ Médica familiar, adscrita al servicio de Urgencias, Unidad 222 del IMSS, Metepec Estado de México.

${ }^{4}$ Infectólogo pediatra, profesor investigador de la Universidad Autónoma de Baja California.

Recibido: 8 de octubre 2018

Aceptado: 4 de abril 2019

\section{Correspondencia}

José de Jesús Coria Lorenzo jjcoril@yahoo.com

Este artículo debe citarse como Coria-Lorenzo JJ, Sierra-Calle AE, Guerrero-Mendoza G, Field-Cortázares J. Influenza y los virus aviar: la amenaza latente de un nuevo virus pandémico. Acta Pediatr Mex 2019;40(3):154-165. 


\section{INTRODUCCIÓN}

En este artículo se hará una analogía de lo más relevante de la enfermedad y de la importancia que en su momento puede representar la enfermedad por influenza aviar y el riesgo de una pandemia por esta cepa.

La influenza es parte de las enfermedades de vigilancia epidemiológica que por sus repercusiones en la salud pública y los costos que representan para el Estado (Gobierno), para las empresas por el ausentismo laboral por la enfermedad en cualquier tiempo (pérdida de días-trabajo-díasproducción), para escuelas en términos de logros del estudiante (aprendizaje) y para el mismo paciente que, en nuestro ambiente, la gran mayoría tiene que pagar su asistencia médica y sus medicamentos. ${ }^{1-3}$

La historia de la influenza se remonta al siglo $X V$, en Italia, donde una epidemia se consideró debida a la "influencia de las estrellas". La primera pandemia debidamente descrita fue la de 1580, originada en Asia, desde donde se dispersó a África y Europa. Hacia el segundo decenio de 1900 tuvo su punto más crítico en 1918, con la influenza española que causó más de 40 millones de muertes a nivel mundial, aunque no hay consenso acerca de su origen (algunos expertos sugieren que se originó en Estados Unidos durante la primavera de 1918, entre el personal militar de Fort Riley, en Kansas). Esta pandemia es la que más muertes ha causado y se la compara con la mortalidad secundaria a las guerras mundiales. El virus de la gripe ha ido evolucionando y cambiando a lo largo de la historia con sus hospederos, aves y mamíferos entre los que se encuentran la especie humana y el cerdo.

En los últimos 10 años ha cobrado gran importancia en los sistemas de salud, debido a las repercusiones del virus pandémico porcino, que no fue otra cosa más que una cepa viral
AH1N1 que sufrió una mutación genética con una cepa porcina.

La historia de las pandemias se remonta a1580 (se cree que participó $\mathrm{A} / \mathrm{H} 3 \mathrm{~N} 2$ vs $\mathrm{A} / \mathrm{H} 2 \mathrm{~N} 2$ ), seguida de las de 1890 y 1900 donde se demostró la participación de los virus $\mathrm{A} / \mathrm{H} 2 \mathrm{~N} 8$ y $\mathrm{A} / \mathrm{H} 3 \mathrm{~N} 8$, respectivamente. En el siglo pasado se experimentaron otros tres acontecimientos pandémicos: el de 1918, pandemia causada por el virus H1N1 con genes de origen aviar, que originó la muerte de 40-50 millones de personas y los de $1957,1968 .^{4-5}$ En la Figura 1 se describe la historia de las pandemias de influenza humana.

La influenza aviar es una enfermedad de origen asiático, el primer virus en aparecer fue el AH5N1 en 1997 con 18 casos de influenza en Hong Kong y desde 2003 hasta el 8 de enero de 2014 que se registró el primer caso en humanos en el continente americano (Canadá, en un viajero que regresaba de China) se habían registrado 648 casos de influenza aviar $\mathrm{AH} 5 \mathrm{~N} 1$ en humanos. Al respecto, la historia se remonta hacia el año 1996 cuando el virus se detectó por primera vez en gansos de China. Este virus AH5N1 de origen asiático conocido como HPAI por sus siglas en inglés (High Pathogenic Virus Influenza A) se detectó en seres humanos en 1997, en medio de un brote originado en aves de corral de Hong Kong. Desde entonces se ha detectado en aves de corral y silvestres en más de 50 países de África, Asia, Europa y Oriente medio. En la actualidad, seis países se consideran endémicos para el virus $\mathrm{AH} 5 \mathrm{~N} 1$ de la forma altamente patógena de la influenza aviar, detectado en aves de corral (Bangladesh, China, Egipto, India, Indonesia y Vietnam). ${ }^{6}$

El objetivo de esta revisión es conocer cómo se han diseminado los virus de influenza aviar en el mundo, evaluar los riesgos de infección y enfermedad, cuáles son las características clínicas de una infección por virus aviar, cuál es el 


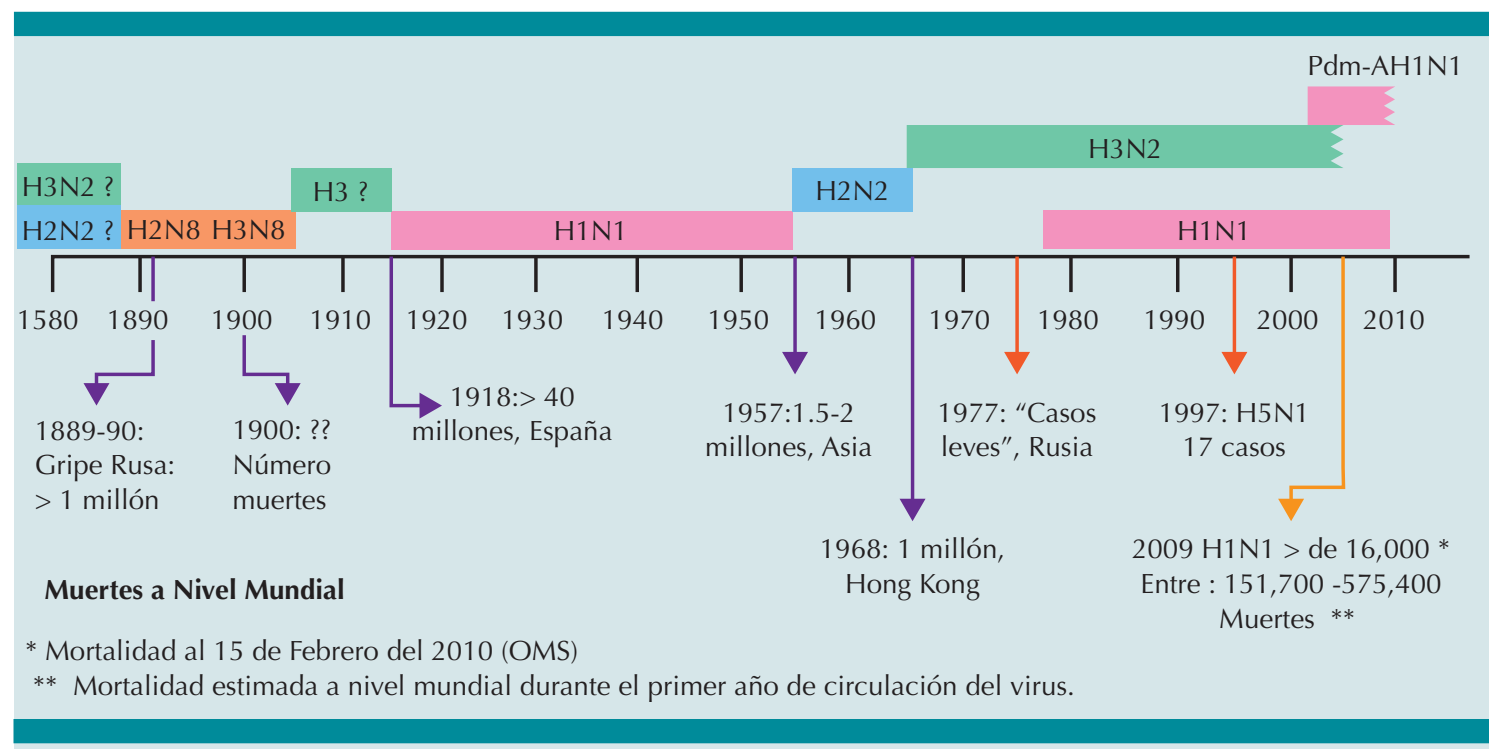

Figura 1. Historia de las pandemias de influenza humana.

tratamiento recomendado hoy en día y, sobre todo, cuáles son las medidas de prevención más recomendables.

\section{Trasmisión del virus}

En el humano, la infección por los virus aviar se adquiere, principalmente, mediante el contacto directo con animales infectados o medios contaminados (trasmisión cruzada), aunque no se produce una trasmisión eficiente ni prolongada entre las personas; es decir, no hay una elevada trasmisión humano-humano. Los pocos casos reportados de trasmisión entre humanos para algunos virus aviar (AH7N7 y AH7N9) son realmente anecdóticos. Hasta la fecha, la trasmisión de esos virus entre personas solo se ha producido en algunos casos en que ha habido un contacto estrecho y prolongado entre un paciente muy enfermo y las personas que lo atendían, incluyendo sus familiares. No se ha registrado una trasmisión sostenida de una persona a otra, pero si estos virus se adaptan o adquieren determinados genes de los virus humanos o de otros virus zoonóticos (puercos, caballos, focas, etc) podrían desencadenar una importante pande- mia. Tampoco existen datos que indiquen que los virus de la influenza aviar y otros virus de origen zoonótico puedan infectar al humano si este consume carne o huevos de aves enfermas debidamente cocinados. Algunos casos humanos de virus de influenza $A(H 5 N 1)$ se han relacionado con el consumo de alimentos preparados con sangre cruda de aves contaminadas. La mayoría de los casos de infección humana por los virus $A(H 5 N 1)$ y $A(H 7 N 9)$ se ha relacionado con el contacto directo o indirecto con aves de corral infectadas, vivas o muertas. ${ }^{7}$

Entre los subtipos de virus de influenza A existen diferencias genéticas y antigénicas que típicamente infectan solo aves y los que pueden infectar aves y humanos. Se consideran dos situaciones: 1) Los virus de influenza aviar han evolucionado en distintos linajes genéticos en diferentes áreas geográficas. 2) Casi todos los cambios genéticos de los diferentes tipos de influenza aviar ocurren en el intestino de las aves migratorias y acuáticas.

El seguimiento y vigilancia epidemiológica son importantes, como los hace la Organización 
Mundial de la Salud en conjunto con los Centros para el Control y Prevención de Enfermedades de Estados Unidos (CDC), para poder determinar el riesgo de trasmisión del virus y la existencia de una nueva pandemia causada por influenza aviar. En las aves migratorias o de corral de comercio internacional se llevan a cabo los arreglos genéticos que causan la infección y enfermedad por influenza aviar, como sucedió con la influenza de 1918 en la que se encontraron genes aviares. ${ }^{8}$

\section{Epidemiología}

Los virus de la influenza A se dividen en subtipos de acuerdo con dos proteínas de la superficie del virus: la hemaglutinina (HA) y la neuraminidasa (NA). Se conocen 18 subtipos hemaglutinina y 11 subtipos neuraminidasa. Todos los subtipos conocidos de los virus de la influenza A pueden causar infecciones en las aves, salvo los subtipos $\mathrm{H} 17 \mathrm{~N} 10$ y H18N11 que solo se han encontrado en murciélagos. Los virus de influenza $A$ han infectado a muchos animales: patos, pollos, pavos, cerdos, caballos, ballenas y focas. Normalmente, estos virus son vistos en una especie $y$, a veces, pueden combinarse (cruza genética) y causar enfermedades en otras especies. Esto crea la oportunidad de que pueda desarrollarse un nuevo virus, nuevas cepas virales quizá muy infecciosas, fácilmente trasmisibles y por demás letales para los humanos. ${ }^{9}$

A lo largo de la historia se han identificado diferentes subtipos del virus de la influenza en el humano y en aves aéreas y acuáticas, pero sobre todo en las de granja y domésticas; esto ha dado como resultado que las cepas pandémicas se ven favorecidas por la variación antigénica. Los diferentes tipos en el humano son: H1N1, H1N2, H2N2, H3N2, H7N7 H7N9, y H10N8. Los subtipos $\mathrm{H} 1 \mathrm{~N} 1$ y los H3N2 han sido los más comunes en términos de historia de la influenza $\mathrm{A}$ en la humanidad. En aves domésticas: el H5N1, H7N9 y H7N7, y la futura amenaza H9N2 se considera que serán los más devastadores. ${ }^{10-13}$

En 1997 se notificaron 18 casos de infección humana por el virus A ( $\mathrm{H} 5 \mathrm{~N} 1-\mathrm{HPAl})$ durante un brote en aves de corral de Hong Kong (Región Administrativa Especial de China). Desde 2003, este virus de la gripe aviar se ha propagado al resto de Asia, Europa y África y en algunos países se ha arraigado en poblaciones de aves de corral. Los brotes han producido millones de casos de infección de estos animales y varios cientos de casos humanos y la muerte de numerosas personas.

Los brotes en aves de corral han tenido gran repercusión en el ámbito del sustento poblacional, de la economía e, incluso, en el comercio internacional de los países afectados. No solo este virus $\mathrm{A}(\mathrm{H} 5)$, con sus diferentes subtipos (AH5N1AH5N8), ha originado brotes de infección en aves de corral y algunos decesos en seres humanos, sino también otros virus como el H7N9, que también se han visto involucrados. De hecho, a partir de 2014, China ha reportado a la OMS 19 casos en humanos confirmados por laboratorio de influenza AH5N6, incluidas 6 defunciones, y también ha identificado que desde mediados del 2017 se han incrementado los brotes en aves de corral en diferentes provincias de China, incluidas en donde se han reportado los casos en humanos.

En cuanto al virus AH5N8 (también HPAI), primeramente detectado en pájaros en Asia en 2014 y desde junio de 2016 por lo menos en 24 países de la Unión Europea, se han reportado brotes en pájaros salvajes y aves de corral, sobre todo en pollos. Esta es la segunda vez que este virus ha causado brote en Europa debido a la migración de aves acuáticas (en particular las que viven alrededor de lagos y ríos). A la fecha no se han reportado casos en humanos por este virus, pero debido a su similitud con otros virus aviar $\mathrm{AH} 5$, la posibilidad de trasmisión al humano no puede excluirse. ${ }^{14,15}$ 
Como tal, los virus H5N1, H7N9 y H7N7 se consideran virus HPAI para las aves de corral, pero no para los humanos; los dos primeros son los principales. En 2013, en China, se notificaron casos de infección humana por un virus A considerado de baja patogenicidad y conocido como Low Pathogenic Influenza A (LPAl); el A(H7N9) se ha propagado entre la población de aves de corral en todo el país y ha causado múltiples brotes y varios cientos de casos y defunciones en humanos. Otros virus de la gripe aviar, en particular los virus $\mathrm{A}(\mathrm{H} 7 \mathrm{~N} 7)$ y $\mathrm{A}(\mathrm{H} 9 \mathrm{~N} 2)$, han provocado infecciones humanas esporádicas. 7,16

El 31 de marzo de 2013 la Comisión de Salud y Planificación Familiar de China notificó a la OMS tres casos de infección humana por virus de la gripe $\mathrm{A}(\mathrm{H} 7 \mathrm{~N} 9)$. Los casos se confirmaron el 29 de marzo mediante pruebas de laboratorio efectuadas por los CDC de China. Desde principios de 2013 hasta la fecha se han notificado, a través del mecanismo del Reglamento Sanitario Internacional, 1566 casos confirmados de infección humana por el virus de la gripe aviar A(H7N9), incluidas 613 defunciones. En 2016 se reportó un evento de trasmisión entre dos miembros del personal médico que tuvieron contacto estrecho con un caso índice por AH7N9. China confirmó, en enero de 2018, el primer caso en humanos por virus aviar $\mathrm{H} 7 \mathrm{~N} 4$, luego de que una mujer de 68 años de la provincia de Jiangsu contrajera el virus. ${ }^{17-20}$

A la fecha se conocen nueve subtipos del virus $\mathrm{H} 7$ causantes de brotes en aves, de los que se han reportado infecciones en el humano por las cepas H7N9, H7N7, H7N4, H7N2 y H7N3. En febrero de 2003, un brote por H7N7-HPAI causó la muerte, en Holanda, de un veterinario (por un cuadro agudo respiratorio) y cuadros de infección leve (sobre todo ocular) en 88 trabajadores de granja y en miembros de sus familias. ${ }^{21,22,23}$

El virus AH9N2 se identificó en marzo de 1999 en dos niños de Hong Kong, que se consideró un nuevo virus con potencial pandémico. Estos virus aislados fueron similares al virus H9N2 aislado de una codorniz en Hong Kong a finales de 1997, aunque diferentes en sus proteínas de superficie (hemaglutinina y neuraminidasa). Una característica notable de estos dos nuevos virus aislados en estos niños es que los seis genes que codifican o integran los componentes internos del virus son similares a los virus tipo AH5N1 aislados en aves (pájaros) y en humanos en 1997. Este rasgo común remarca la aparente propensión de este virus aviar, con este complemento genético, para infectar al humano y destacar el potencial emergente de la aparición de un nuevo virus pandémico patógeno para el humano, que ha permanecido silente y solo con gran mortandad en aves de corral. Los estudios en tejidos de animales han demostrado que este virus tiene la capacidad de infectar al cerdo, loros y pinzones. ${ }^{24-25}$

También en 2013, autoridades médicas de la provincia de Jiangxi, en el oriente de China, informaron el deceso de una mujer de 76 años el 6 de diciembre, a causa de un cuadro neumónico grave por virus aviar H10N8 que adquirió el 30 de noviembre, que nunca había afectado a humanos. El segundo caso en la misma provincia se identificó el 26 enero de 2014. Los expertos encontraron 5 genes en ambos casos de virus compatibles con H9N2 de brotes pasados de influenza aviar en pollos, por lo que se alertó no subestimar una posible pandemia en el humano por este virus, en virtud de su fácil replicabilidad en éste, aunque a la fecha no hay una amenaza inmediata. ${ }^{26,27}$

\section{Evaluación de riesgos}

El principal factor de riesgo de infección humana por los virus de la influenza aviar parece ser la exposición directa o indirecta a aves de corral infectadas, enfermas o muertas, o a entornos contaminados como los mercados donde se 
comercia con aves vivas. El sacrificio, desplume, manipulación de las carcasas y preparación para el consumo de éstas, especialmente en el entorno doméstico, quizá sean también factores de riesgo. Poco común pero documentado (a pesar de que se desconoce la trasmisión real) es el contacto estrecho y prolongado con un enfermo grave. ${ }^{7}$

Otros factores de riesgo que continúan en evaluación son: ¿Si los individuos infectados de aéreas afectadas pueden efectuar viajes internacionales? ¿Y si los productos de animales enfermos deben comercializarse abiertamente?

Un factor de impacto de riesgo es el que el 30 de agosto de 2018, el periódico The New York Times publicó como una alerta grave en cuanto a que China, durante más de un año, se había negado a entregar muestras del virus aviar $\mathrm{H} 7 \mathrm{~N} 9$ de alta patogenicidad. Si se considera que desde su origen en China en 2013, el virus se ha esparcido por granjas avícolas, hasta evolucionar a una cepa con un grado muy alto patogénico que puede infectar a los humanos, si ésta llegase a contagiarse entre humano-humano, las vacunas estacionales serían de nula protección. Esto porque la mayoría de la población mundial no tiene algún grado de inmunidad hacia este virus, aunado a que no se dispondría de ningún tipo de biológico para evitar su propagación.

Y, por último, la migración de las aves silvestres juega un papel importante como factor de riesgo debido a la diseminación y diversificación genética de las clades (árbol genealógico), sobre todo de los virus $\mathrm{H} 5$ de alta patogenicidad. Recuérdese que éstas son portadoras del virus en el aparato respiratorio o intestinal. ${ }^{24,25,28-31}$

\section{Repercusiones de la enfermedad}

Un evento pandémico de influenza tiene el potencial de causar más muertes y enfermedad que otras situaciones que amenacen la salud pública. Por ejemplo, si el día de hoy emergiera un virus de influenza pandémica, con la virulencia similar a la de 1918, en ausencia de intervenciones seguras, convenientes y precisas, podrían morir 1.9 millones de personas y 10 millones requerirían hospitalización en el curso del brote pandémico, que puede durar entre 11 y 14 meses. ${ }^{4,5}$

Cuando surge una nueva cepa pandémica del virus, 25 a 35\% de la población podría padecer la enfermedad clínica, y una fracción sustancial de estas personas podrían morir. ${ }^{9}$

Las pandemias de influenza (brotes que afectan a gran parte del mundo por la aparición de un nuevo virus) son acontecimientos impredecibles, pero recurrentes que pueden tener consecuencias sanitarias, económicas y sociales en el mundo entero. Éstas, como es sabido, se producen por la convergencia de dos factores decisivos: la aparición de un virus de influenza aviar o de influenza de origen zoonótico capaz de causar una trasmisión sostenida de persona a persona, y la escasa o nula inmunidad de la población frente a ese virus.

La circulación continua de algunos subtipos del virus de influenza aviar en aves de corral, como los $\mathrm{A}(\mathrm{H} 5)$ o $\mathrm{A}(\mathrm{H} 7 \mathrm{~N} 9)$, son de importancia para la salud pública porque esos virus suelen causar enfermedades graves en las personas y pueden sufrir mutaciones que faciliten la trasmisión entre ellas, como el LPAI virus AH7N9 que parece infectar al humano más fácilmente que las cepas HPAI de AH5N1. ${ }^{7}$

\section{Características clínicas de los virus aviar}

Las infecciones por virus de influenza aviar y otros virus de origen zoonótico (porcino) en las personas pueden causar: conjuntivitis leve, cuadro gripal, neumonía grave o, incluso, la 
muerte. Las características de la enfermedad, como el periodo de incubación, la gravedad de los síntomas y el cuadro clínico, dependen del subtipo causante de la infección.

Por lo que se refiere a las infecciones por el virus de la gripe aviar $\mathrm{A}(\mathrm{H} 5 \mathrm{~N} 1)$ en las personas, los datos más recientes indican que el periodo medio de incubación es de entre 2 y 5 días, aunque puede prolongarse hasta 17 días. En cuanto a las infecciones humanas por el virus $\mathrm{A}(\mathrm{H} 7 \mathrm{~N} 9)$, el periodo de incubación es de entre 1 y 10 días, con una media de 5 días. Para ambos virus, el periodo de incubación promedio es más prolongado que el de la influenza estacional (2 días). En lo referente a las infecciones humanas por el virus de la influenza porcina, se ha notificado un periodo de incubación de entre 2 y 7 días. ${ }^{32,33}$

En muchos pacientes infectados por virus de influenza aviar $\mathrm{A}(\mathrm{H} 5)$ o $\mathrm{A}(\mathrm{H} 7 \mathrm{~N} 9)$, la enfermedad ha seguido una evolución clínica agresiva. Los síntomas iniciales comunes son: fiebre alta (igual o superior a $38^{\circ} \mathrm{C}$ ) y tos. Se han notificado signos y síntomas de afección de las vías respiratorias inferiores: disnea o dificultad para respirar. Los síntomas de afectación de las vías respiratorias superiores, como la faringoamigdalitis o la coriza son menos comunes. También se han notificado otros síntomas: diarrea, vómitos, dolor abdominal, sangrado por la nariz y encías y dolor torácico en la evolución clínica de algunos pacientes. Entre las complicaciones que puede originar la infección están: hipoxemia, disfunción orgánica múltiple e infecciones secundarias bacterianas y fúngicas. La tasa de mortalidad de las infecciones por el virus del subtipo $\mathrm{A}(\mathrm{H} 5)$ y $A(H 7 N 9)$ en las personas es muy superior a la de las infecciones por el virus de la influenza estacional.

En el caso de las infecciones humanas por los virus de la gripe aviar A(H7N7) y A(H9N2), la enfermedad suele ser leve o subclínica. Solo se ha notificado una infección humana letal por el virus $\mathrm{A}(\mathrm{H} 7 \mathrm{~N} 7)$ en Holanda. ${ }^{33}$ En cuanto a las infecciones humanas por los virus de la gripe porcina, la mayoría de los casos han sido leves, pocos han precisado hospitalización y se han notificado muy pocas defunciones. Las infecciones en el humano por virus H7N2, H7N3, H7N4 y el mismo H7N7 son cuadros leves a moderados con síntomas que incluyen conjuntivitis o en el aparato respiratorio superior. ${ }^{18-33}$

El conocimiento de las características clínicas de los virus aviar permite reconocer que el riesgo potencial de estos virus es la modificación en sus genes de letalidad y contagiosidad y, sobre todo, si ocurre lo último, habrá que presuponer que tiene el potencial de matar a millones de humanos y, de hecho, es prioridad de la OMS, con insistencia en la: Influenza Risk Assessment Tool (herramienta de evaluación del riesgo de influenza, IRAT). Esta herramienta se creó en los CDC por expertos externos en influenza para evaluar el riesgo potencial de pandemia que suponen los virus de la influenza A que circulan actualmente en animales, pero no en seres humanos. La IRAT permite evaluar el riesgo potencial de pandemia de acuerdo con dos escenarios diferentes: "aparición" y "repercusiones en la salud pública". ${ }^{34}$

\section{Tratamiento recomendado}

El oseltamivir puede reducir la duración de la fase de replicación del virus y mejorar las perspectivas de supervivencia. ${ }^{31}$ En los casos sospechosos debe prescribirse lo antes posible (de preferencia en las 48 horas siguientes al inicio de los síntomas) para que se puedan obtener los máximos beneficios terapéuticos. Ante la importante mortalidad actual de la infección por virus de los subtipos $\mathrm{A}(\mathrm{H} 5)$ y $\mathrm{A}(\mathrm{H} 7 \mathrm{~N} 9)$ y las pruebas de que los virus se replican durante largos periodos en esta enfermedad, también debe considerarse la posibilidad de administrar el fármaco en fases más tardías de la enfermedad. 
En caso de infección grave por los virus $\mathrm{A}(\mathrm{H} 5)$ o $\mathrm{A}(\mathrm{H} 7 \mathrm{~N} 9)$ y comorbilidades serias (obesidad, asma, hipertensión, diabetes mellitus, etc.), el clínico puede considerar necesario aumentar la dosis diaria recomendada o la duración del tratamiento. La absorción del fármaco puede ser deficiente en pacientes con infección grave por virus $\mathrm{A}(\mathrm{H} 5)$ o $\mathrm{A}(\mathrm{H} 7 \mathrm{~N} 9)$ o con síntomas gastrointestinales graves. ${ }^{?}$

Recientemente, la FDA aprobó un nuevo medicamento antiviral contra la influenza, de administración una sola vez al día (baloxavirmarboxil [Xofluza ${ }^{\circledR}$ ). Por ahora solo está autorizado para personas de 12 años en adelante que han tenido síntomas de la influenza durante al menos 2 días y con un cuadro sin complicaciones. Además, por el momento los CDC no recomiendan su indicación a mujeres embarazadas, madres lactantes, pacientes ambulatorios con enfermedades progresivas o con complicaciones o pacientes hospitalizados. En virtud de su novedoso mecanismo de acción, que consiste en inhibir la endonucleasa de casi todos los tipos de influenza en estudios fase II y fase III, Baloxavir demostró un efecto antiviral contra una amplia gama de virus de la influenza que incluyen cepas resistentes a oseltamivir y cepas aviares (H7N9, H5N1). ${ }^{35-40}$

\section{Medidas de prevención}

El control de la enfermedad en los animales es decisivo para reducir el riesgo en el humano. La infección humana por los virus de influenza de origen zoonótico puede seguir produciéndose. Para minimizar el riesgo de salud pública es fundamental asegurar que la vigilancia sea cualitativa de las poblaciones humanas y animales, que la investigación sea exhaustiva de cada caso de infección humana y que la planificación de la pandemia se base en los riesgos.

El control de la circulación de los virus de influenza aviar en las aves de corral es decisivo para reducir el riesgo de infección humana. Ante la persistencia de los virus $\mathrm{A}(\mathrm{H} 5)$ y $\mathrm{A}(\mathrm{H} 7 \mathrm{~N} 9)$ en algunas poblaciones de aves de corral, el control exigirá un compromiso a largo plazo por parte de los países y una estrecha coordinación entre las autoridades de salud pública y de sanidad animal. ${ }^{9}$

Los médicos deben considerar la posibilidad de infección por influenza aviar, y en especial por AH7N9, en el paciente con síntomas respiratorios luego de 10 días de haber viajado a China, sobre todo si tuvo exposición a pájaros o aves de corral en mercados al aire libre. Esto, independientemente de ser niño o adulto. Hay que recordar que la infección principalmente causa un cuadro leve pero muchos casos resultan en una enfermedad respiratoria severa.

Entre las recomendaciones en el humano se sugieren: a) en caso de viajar a China y regresar con síntomas de influenza, acudir inmediatamente al médico y evitar el contacto estrecho con otras personas; $b$ ) evitar compartir utensilios de comida o personales con otros individuos; $c$ ) toser o estornudar con la técnica del codo. Entre otras medidas en caso de sospecha de un brote aviar se aconseja: 1) lavado constante de manos; 2) no consumir alimentos en la vía pública; 3) no comprar animales de corral de dudosa procedencia; 4) siempre cocinar adecuadamente su carne y derivados; 5) no usar su sangre para preparar alimentos; 6) evitar el comercio internacional ilegal. ${ }^{41}$

La OMS, la Organización Mundial de Sanidad Animal (OIE) y la Organización de las Naciones Unidas para la Alimentación y la Agricultura (FAO) colaboran para detectar y evaluar el riesgo de aparición de los virus de influenza aviar y otros virus de origen zoonótico de importancia para la salud pública. Los reportes actualizados de la evaluación de riesgos y las recomendaciones para las intervenciones son comunicados oportunamente a los estados miembros, con el 
propósito de mejorar el nivel de preparación y respuesta ante una eventual nueva pandemia., ${ }^{7,42}$

A pesar de los esfuerzos de la OMS, los CDC y otras organizaciones, la dificultad para poder desarrollar una vacuna eficiente y efectiva, además de costo-benéfica, será seguramente muy difícil, ello debido a las múltiples combinaciones de sus clades (árboles filogenéticos de hemaglutinina y neuraminidasa) de cada uno de los diferentes virus aviar, lo que dificulta tener existencias de vacunas de influenza aviar. Por poner un ejemplo y entender mejor esta barrera, una clade es una agrupación que incluye a un antepasado común y todos los descendientes (vivos y extinguidos) de aquel antepasado. La clade emplea una filogenia (árbol filogenético) que es fácil contar, donde cada grupo de linajes forma un clade. Imagine desprender una rama sola del árbol filogenético; todos los organismos en aquella rama podada arreglarán una clade. ${ }^{8}$ Figura 2

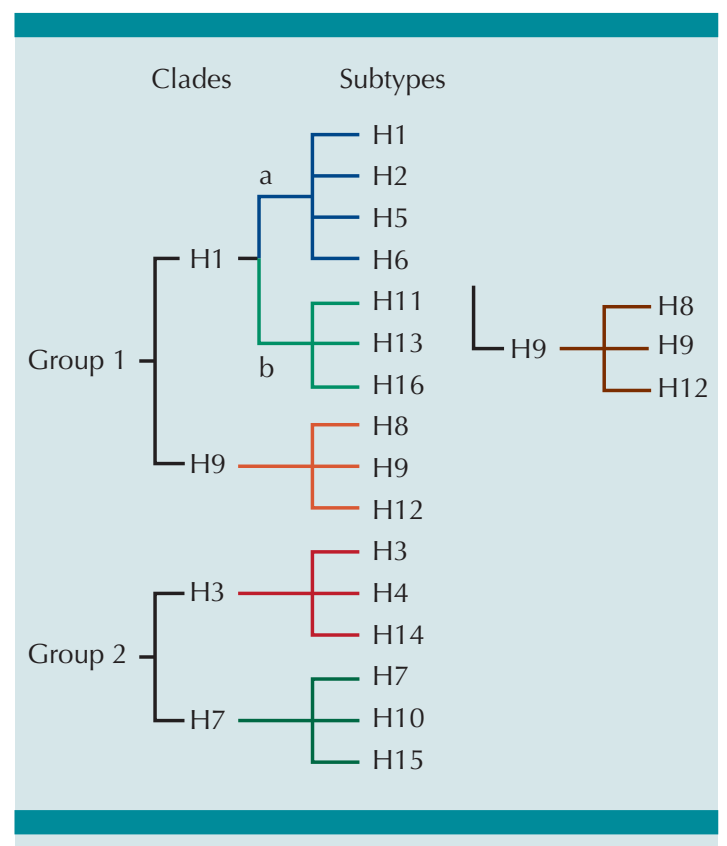

Figura 2. Árbol filogenético y Clade de un grupo de linajes de influenza aviar.
La magnitud en extensión del linaje tan solo del virus influenza aviar AH5N1, por poner un ejemplo de su filogenia y sus diferentes clades, hacen ver lo difícil que sería disponer de una vacuna ideal solo para esta cepa de virus aviar y obvio mucho más difícil hacer una mezcla (pool) de las diferentes cepas potencialmente patógenas para el humano. En la Figura 3 se muestra el linaje y clades de influenza aviar AH5N1 identificadas solo en Indonesia desde 1996 hasta 2015, donde su antecesor fue: A/goose/Guangdong/1996, con tres diferentes reacomodos en 2012 y dos nuevas cepas en 2013. ${ }^{43}$

Recientemente, en un comunicado el 11 marzo de 2019, Tedros Adhanom Ghebreyesus, director general de la OMS, dijo: "la amenaza de una gripe pandémica siempre existe. Debemos estar atentos y preparados: el costo de un gran brote de gripe será mucho mayor que el precio de la prevención", alertó, y aseveró que la próxima pandemia de gripe "es cuestión de cuándo, no de si se producirá". Quizá la próxima pandemia pueda ser por un virus aviar. Ante esto solo queda tener en mente las recomendaciones de prevención y, en su momento, el tratamiento oportuno antiviral. ${ }^{44}$ Figura 3

\section{CONCLUSIONES}

Si bien es cierto que la última pandemia fue causada por un virus zoonótico AH1N1sw (porcino) en abril del 2009, gracias a la red de vigilancia mundial de la distribución de este y otros virus hoy se sabe que en México, como en muchos otros países, la temporada alta de diseminación de la influenza estacional, mal Ilamada aún pandémica AH1N1, es de la semana epidemiológica 50-52 a la 10-12 del año siguiente. ${ }^{45,46} \mathrm{El}$ riesgo global para la salud pública de los virus de influenza aviar actualmente conocidos en la interface humano-animal-humano, a pesar de que no ha cambiado, y la probabilidad de trasmisión sostenida de humano a humano de 


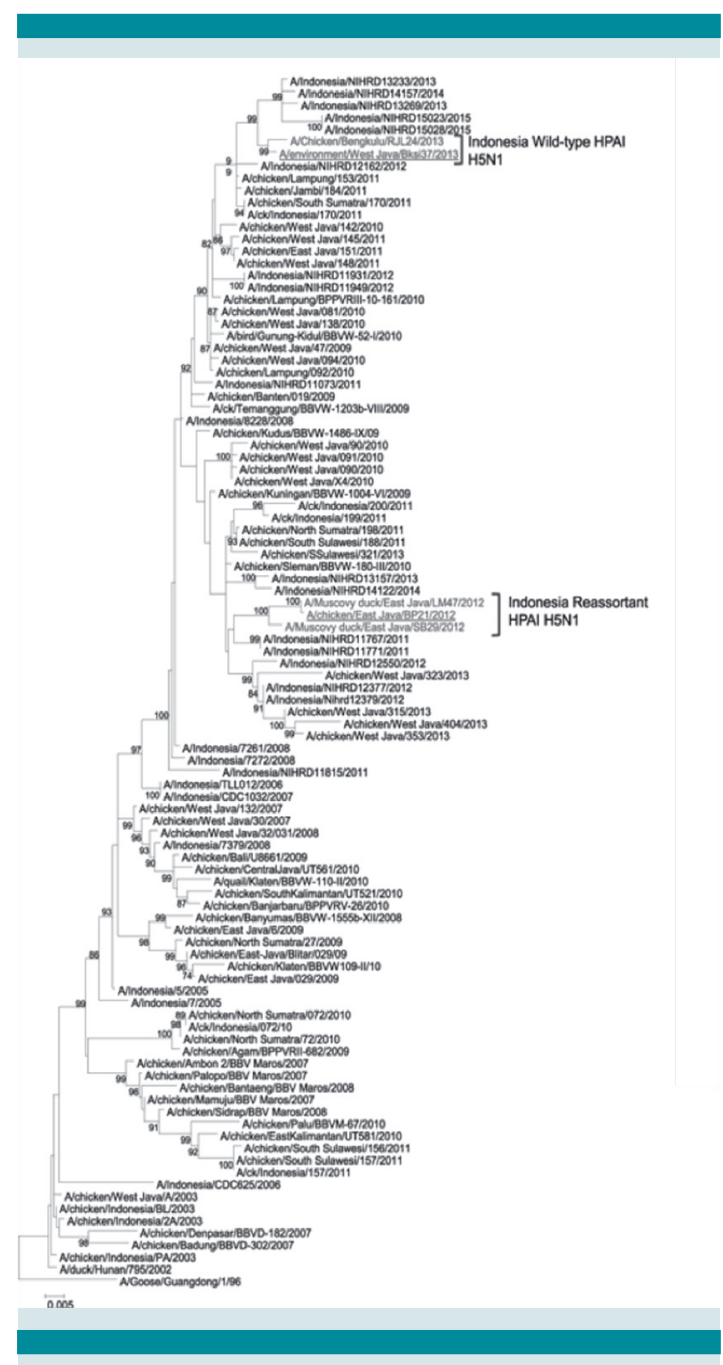

Figura 3. Árbol filogenético de AH5N1 en Indonesia desde 1996 hasta el 2015.

estos virus permanece baja; no se tiene un mapa epidemiológico mundial en el humano que permita predecir un posible evento de brote. No obstante, con el aumento del comercio mundial y los viajes, una epidemia localizada puede convertirse, rápidamente, en una pandemia, que dejará poco tiempo para preparar una respuesta de salud pública.

Se ignora si los virus de influenza aviar y los otros virus de origen zoonótico que circulan actualmente darán lugar a una pandemia en el futuro. Lo cierto es que lo peor que pudiese ocurrir es que sea ocasionada por el AH9N2, aunque parece ser que se adelantará un evento pandémico por AH7N9. Ante la diversidad de los virus de influenza aviar y de los propios de origen zoonótico que han causado infecciones humanas es necesario mantener una vigilancia constante en las poblaciones animales y humanas, Ilevar a cabo una investigación exhaustiva de los casos de infección humana y una planificación de la pandemia basada en el riesgo, como lo viene haciendo la OMS con el acuerdo de que los países participantes deben transferir "de manera oportuna" muestras de influenza con potencial pandémico a los centros de investigación designados, porque como tal, las infecciones adicionales o nuevas con virus de origen animal o zoonóticas son una realidad esperada.

Hoy en día (abril del 2019) debido a que Estados Unidos y China tienen una "guerra" comercial, algunos científicos temen que el intercambio vital de suministros médicos e información pueda lentificarse, lo que obstruirá la prevención de la siguiente amenaza biológica. Los expertos coinciden en que es probable que la siguiente pandemia mundial de influenza provenga de un agresor reincidente: el virus $\mathrm{H} 7 \mathrm{~N} 9$ es uno de los candidatos.

\section{REFERENCIAS}

1. Lu PJ Santibanez TA, Williams WW, et al. Surveillance of influenza vaccination coverage United States, 200708 through 201112 influenza seasons. MMWR Surveill Summ. 2013;62(Suppl 4):129. https://www.jstor.org/ stable/24806080

2. How the Flu Virus Can Change: "Drift" and "Shift". cdc.gov/ enes/flu/about/viruses/change.htm 19 ago.2014.

3. Recommended composition of influenza virus vaccines for use in the 20142015 northern hemisphere influenza season WHO.http://www.who.int/influenza/vaccines/ virus/recommendations/2014_15_north/en/

4. Ayora GT. Influenza: Historia de una enfermedad. Rev Biomed 1999; 10:5761. 
5. Virus de la influenza aviar A(H5N1) altamente patógena de origen asiático https://espanol.cdc.gov/enes/flu/avianflu/ h5n1virus.htm

6. Primer caso de infección por el virus de la influenza aviar (H5N1) altamente patógeno en América. https://espanol. cdc.gov/enes/flu/news/firsthumanh5n1americas.htm

7. Influenza (Avian and other zoonotic) http://www.who.int/ es/newsroom/factsheets/detail/influenza(avianandotherz oonotic) access 13 November 2018.

8. Medina RA, GarcíaSastre A. Influenza A viruses: new research developments. Nature Reviews Microbiology. 2011;(9):590-603.

9. WHO Global Influenza Preparedness Plan. The role of WHO and recommendations for national measures before and during pandemics. WHO/CDS/CSR/GIP/2005.5 Department of Communicable Disease Surveillance and Response Global Influenza Programme. World Health Organization 2005:453.

10. Grohskopf L, et al. MMWR.Morb Mortal Wkly Rep.2014;63(32):69197.

11. Topics about seasonal influenza vaccines. http://ecd.europa. eu/en/healthtopics/seasonal_influenza/vaccines/Pages/ influenza_vaccination.aspx

12. Epidemiology and Prevention of VaccinePreventable Diseases CDC.http://www.cdc.gob/vaccines/pubs/pinkbook/ fluhtlm.

13. Los virus de la influenza tipo A https://espanol.cdc.gov/enes/ flu/avianflu/influenzaavirussubtypes.htm

14. Yang ZiFeng, et al. Human Infection with a Novel Avian Influenza A(H5N6) Virus. N. Engl.J.Med.2015;373(5):48789. DOI: 10.1056/NEJMc1502983

15. Adlhoch $\mathrm{C}$, et al. Protective Measures for Humans against Avian Influenza A(H5N8) Outbreaks in 22 European Union/ European Economic Area Countries and Israel, 2016-17. Emerging Infectious Diseases. 2018; 24(10):18. doi: 10.3201/ eid2410.180269

16. WHO. 2 January 2013, posting date. Cumulative number of confirmed human cases of avian influenza $A(H 5 N 1)$ reported to WHO. World Health Organization, Geneva, Switzerland. http://www.who.int/influenza /human_animal_interface/ ENGIP_20130705CumulativeNumberH5N 1cases_2

17. Infección humana por virus de la gripe aviar $A(H 7 N 9)$ en China http://www.who.int/csr/don/2013_04_01/es/

18. China: Se confirma el primer caso humano de gripe aviar. www.avicultura.com/.chinaseconfirmaelprimercasohumanodegripeaviarh7n4.

19. Artois J, et al. Changing Geographic Patterns and Risk Factors for Avian Influenza A(H7N9) Infections in Humans, China. Emerg Infect Dis J. 2018; 14(1):87-94. doi: 10.3201/ eid2401.171393.

20. Farooqui $A$, Liu $W$, Zeng $T$, Liu $Y$, Zhang L, Khan A, Wu X, Wu R, et al. Probable Hospital Cluster of H7N9 Influenza Infection. N. Engl J. Med. 2016;374(6):596-98. DOI: 10.1056/ NEJMc1505359.
21. Bos ME, et al. High probability of avian influenza virus (H7N7) transmission from poultry to humans active in disease control on infected farms. J Infect Dis. 2010. 201(9):1390-96. https://doi.org/10.1086/651663

22. Du Ry van Beest, Meijer A, Koopmans M, de Jager CM, van de Kamp E, Wilbrink B. et al. Human to human transmission of avian influenza A/H7N7, The Netherlands, 2003. Eurosurveillance Monthly 2005; 10;12:3-4. DOI: 10.2807/ esm.10.12.00584-en

23. Shaw $M$, et al. Avian to human transmission of H9N2influenza A viruses: relationship between $\mathrm{H} 9 \mathrm{~N} 2$ and $\mathrm{H} 5 \mathrm{~N} 1$ human isolates. Proc NatlAcad Sci USA, 2000;97: 9654-58. https://doi.org/10.1073/pnas.160270697

24. Lenny BJ, et al. Replication Capacity of Avian Influenza $A(H 9 N 2)$ Virus in Pet Birds and Mammals, Bangladesh. Emerg Infect Dis. 2015 Dec; 21(12): 2174-77. doi: 10.3201/ eid2112.151152

25. China has retained samples of a dangerous influenza virus https://www.nytimes.com/es/2018/08/30/chinavirusinfluenza/ By Emily Baumgaertner August 30, 2018

26. Alarma en China tras confirmarse la primera muerte por el nuevo virus de la gripe aviar. Medscape en español. https:// www.taringa.net/posts/noticias/17545842/Alertaenchinanuevagripeaviarcausa1ermuerte.html

27. Aparece en China nueva cepa "mortal" de gripe aviar. https://www.bbc.com/mundo/noticias/2014/02/140204_ socios gripe aviar china ao

28. Phylogenetic trees of the internal genes of influenza virus A (H10N8 https://www.researchgate.net/figure/PhylogenetictreesoftheinternalgenesofinfluenzavirusAH10N8isolatesfrom_fig2_268978098

29. China: Shanghai reported a human H7N9 AIV case. http:// www.flu.org.cn/en/news_detail?action=ql\&uid=MjI0OA\&

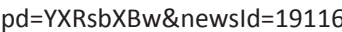

30. WHO: Human infection with avian influenza $A(H 7 N 9)$ virus China (Mutation, Risk accessment) http://www.flu.org.cn/ en/news_detail?action=ql\&uid=MjIOOA\&pd=YXRsbXBw\& newsld=19117

31. Control of Communicable Diseases Manual 20th Edition American Public Health Association (2015). APHA Press, Washington DC. ISBN: 9780875530185

32. Li $Q$, et al. Epidemiology of Human Infections with Avian Influenza A(H7N9) Virus in China. New England J Med 2014; 370:520-32. doi: 10.1056/NEJMoa1304617

33. Jonges $M$, et al. Emergence of the VirulenceAssociated PB2 E627K Substitution in a Fatal Human Case of Highly Pathogenic Avian Influenza Virus A(H7N7) Infection as Determined by Illumina UltraDeep Sequencing. Journal of Virology. 2014; 88(3): 16941702. http://dx.doi.org/10.1128/JVI.02044-13.

34. Influenza Risk Assessment Tool (IRAT): CDC (Flu). https:// www.cdc.gov/flu/pandemicresources/nationalstrategy/ riskassessment.htm

35. Medicamento antiviral contra la influenza: baloxavir marboxil Influenza Antiviral Drug Baloxavir Marboxil | CDC 
Coria-Lorenzo JJ, et al. Influenza aviar: nueva pandemia latente

36. Hayden FG, et al. Baloxavir Marboxil for Uncomplicated Influenza in Adults and Adolescents, N Engl J Med. 2018; 379:913-23. DOI:10.1056/NEJMoa1716197. DOI: 10.1056/ NEJMoa1716197

37. Taniguchi K, et al. Inhibitory Effect of S033188, a novel inhibitor of influenza virus cap-dependent endonuclease, against avian influenza A/H7N9 virus in vitro and in vivo. Poster presentation at ESWI, September 2017.

38. Taniguchi $\mathrm{K}$ et al. Inhibitory Effect of S033188, a novel inhibitor of influenza virus capdependent endonuclease, against highly pathogenic avian influenza virus A/H5N1. Poster presentation at ECCMID, April, 2017.

39. Influenza Antiviral Drug Baloxavir Marboxil. https://www. cdc.gov/flu/about/qa/baloxavirmarboxil.htm

40. FDA approves new drug to treat influenza. FDA News Release. October 24, 2018

41. https://www.fda.gov/NewsEvents/Newsroom/PressAnnouncements/ucm624226.htm

42. Interim Guidance on Testing, Specimen Collection, and Processing for Patients with Suspected Infection with Novel
Influenza A Viruses with the Potential to Cause Severe Disease in Humans. https://www.cdc.gov/flu/avianflu/ severepotential.htm WHO Global Influenza Surveillance and Response System (GISRS) Surveillance and Vaccine Development WHO.http://www.influenzacentre.org/ centre_GISRS.htm

43. Dharmayanti NLP, et al. Attenuation of highly pathogenic avian influenza $\mathrm{A}(\mathrm{H} 5 \mathrm{~N} 1)$ viruses in Indonesia following the reassortment and acquisition of genes from low pathogenicity avian influenza A virus progenitors. Emerging Microbes \& Infections (2018) 7:147. https://doi.org/10.1038/ s41426-018-0147-5

44. Alerta OMS de una "inevitable" pandemia de gripe https:// www.excelsior.com.mx/global/alertaomsdeunainevitablepandemiadegripe/1301133. Consultado 11marzo del 2019.

45. Coria JJL, et al. Morbilidad de la influenza en el Estado de México: a siete años de la pandemia. Neumol Cir Torax. 2017; 76 (1): 1723.

46. Coria JJL, et al. Influenza en el Estado de México: de la pandemia a la endemia. Sal Pub. Mex. 2017; 59 (6): 605-07. http://dx.doi.org/10.21149/8391 